\title{
The English Nominal Group Structure with Special Reference to John Kerry and Ban Ki-moon's Speech
}

\author{
Ni Kadek Indah Suryadewi \\ English Department, Faculty of Arts, Udayana University \\ [nikadekindahsuryadewi@gmail.com] \\ *Corresponding Author
}

\begin{abstract}
This study entitled The English Nominal Group Structure with Special Reference to John Kerry and Ban Ki-Moon's Speech is aimed to analyze the experiential structures and logical structure elements of nominal group used by John Kerry and Ban Ki-moon in their speech. The data were taken from the transcript of John Kerry and Ban Kimoon's speech at the United States Department of State in Washington, D.C. on February 14, 2013. Descriptive qualitative method was applied to analyze the experiential and logical structures of nominal group. The theory used to analyze it is the theory of Nominal Group proposed by Halliday and Matthiessen in the book entitled Halliday's Introduction to Functional Grammar the fourth edition. The result of analysis shows that in the experiential structure, T structure becomes the most frequent structure that occurs followed by $D+T$ and $D+T+Q$ structure. Meanwhile, in the logical structure, $H$ and $M$ are the logical structure elements found. Therefore, from the structures found, John Kerry and Ban Ki-moon's nominal group structures have a simple construction and it emphasizes Thing without adding any information.
\end{abstract}

Keywords: Functional Grammar, Speech, Nominal Group

\begin{abstract}
Abstrak
Penelitian ini bertujuan untuk menemukan struktur experiential dan elemen struktur logis pada grup nominal yang digunakan oleh John Kerry dan Ban Ki-moon dalam pidato mereka. Data diambil dari transkrip pidato John Kerry dan Ban Ki-moon pada Departemen Luar Negeri Amerika Serikat di Washington D.C. pada tanggal 14 Februari 2013. Metode deskriptif kualitatif diterapkan untuk menemukan struktur experiential dan logis pada grup nominal. Teori yang digunakan untuk menganalisis data adalah teori Grup Nominal yang diusulkan oleh Halliday dan Matthiessen. Hasil analisis menunjukkan bahwa dalam struktur experiential, struktur T menjadi struktur yang paling sering muncul dan diikuti oleh struktur $D+T$ dan struktur $D+T+Q$. Sementara itu, dalam struktur logis, $H$ dan $M$ merupakan element struktur logis yang ditemukan. Oleh karena itu, dari struktur yang ditemukan, struktur grup nominal pada pidato mereka mempunyai bentuk yang sederhana dan menekankan "element Thing" tanpa menambahkan informasi lain.
\end{abstract}

Kata kunci: Functional Grammar, Pidato, Grup Nominal

\section{Background of the Study}

Language as a means of communication has an important role in the interaction among the people (Lintang, 2013). Language is used for communication among people in a particular country over a period of time. There are several kinds of language which are used to communicate by the people are body language, written 
language, and spoken language. Those kinds of language are usually used by the people to deliver the message from the speaker to the hearer.

The spoken language or in this case, the speech of John Kerry and Ban Kimoon was related to this study, the structure of their group of words especially Nominal Group in the speech would be analyzed. John Kerry is an American politician who served as the 68th United States Secretary of State from February 1st, 2013 - January 20th, 2017 and Ban Ki-moon is a South Korean diplomat who was the eighth Secretary-General of the United Nations from January 1st, 2007 to December 31 st, 2016.

This study is concerned with the Nominal Group of the short speech in delivering remarks during the United Nations general meeting at the United States Department of State in Washington, D.C. on February 14th, 2013.

In analyzing the Nominal Group in the speech, the Theory of Nominal Group proposed by Halliday \& Matthiessen (2014) in the book entitled Halliday's Introduction to Functional Grammar the fourth edition was used. According to the Theory of Nominal Group in the book entitled Halliday's Introduction to Functional Grammar (2014:362), a group is a combination of words that are built up on the basis of a particular logical relation.

Previously, the study about Nominal Group was rarely discussed in speech. In 2014, there was a study about Nominal Group by Kartini Bangun, but she discussed the Nominal Group within Batak Karo Language and the same study in 2013, Lintang Karina discussed the Nominal Group in opinion articles in the Jakarta Post. Therefore, from those studies, it becomes the reason why the researcher is interested in discussing the
Nominal Group in speech. The spoken language of John Kerry and Ban Kimoon especially in the Nominal Group in the speech was analyzed because the previous studies had discussed the written one.

\section{Problems of the Study}

a) What experiential structures of nominal group are found in John Kerry and Ban Ki-moon's speech?

b) What logical structure elements are found in John Kerry and Ban Kimoon's speech?

\section{Aims of the Study}

a) To find out the experiential structures of nominal group found in John Kerry and Ban Ki-moon's speech.

b) To find out the logical structure elements of nominal group found in John Kerry and Ban Ki-moon's speech.

\section{Research Method}

In the research method, there are four elements referring to the problems already formulated, namely: data source, method and technique of collecting data, method and technique of analyzing data, and method and technique of presenting analysis. These methods are described as follows:

\subsection{Data Source}

The data source of this study is the transcript of the speech of John Kerry, the $68^{\text {th }}$ United States Secretary of State and Ban Ki-moon, the $8^{\text {th }}$ United Nations Secretary General in United States. The speech is about John Kerry and Ban Kimoon's speech during the United Nations general meeting at the United States Department of State in Washington, D.C. on February $14^{\text {th }}, 2013$. the source is exquisitely special because this is the first time UN has spoken during the 
humanitarian issues especially refugees from regime's countries.

\subsection{Method and Technique of Collecting Data}

The data were collected using the documentation method. This method was applied to the transcript of John Kerry and Ban Ki-moon's speech in Washington D.C., which had been downloaded from USA's government official website. The technique that was used in this study was note taking through several steps as follows: reading the transcript, taking a note, and selecting the data.

\subsection{Method and Technique of Analyzing Data}

The collected data were analyzed by applying descriptive qualitative method, since the data was not in the numerative form. The data were analyzed using descriptive technique and the steps of analyzing data are described as follows: presenting the relevant data, meaning that the collected data consisting of nominal group were used by those speakers. Next, identifying and classifying the collected data based on the theory in order to find out the experiential structure elements of each experiential structure of the nominal group. The last step was analyzing those structures according to the theory in order to find out the logical structure of the elements of those structures.

\subsection{Method and Technique of Presenting Analysis}

In presenting the analysis of the first and second problems, the formal and informal methods were applied, since the analysis was presented in words and symbols. In presenting the data, several steps were taken. Firstly, the data were categorized into the structures of nominal group and they were presented in the form of symbol and elaborated in the form of paragraph. The second step was analyzing the logical structure elements of the nominal group in the form of symbol and elaborating in the form of paragraph.

\section{Result and Discussion \\ 5.1 Preliminary}

The data that had been analyzed was the Nominal Group in the speech of John Kerry and Ban Ki-moon in Washington D.C. In the data, there are 440 nominal groups that had been found and analyzed. However, in this result and discussion, only several nominal groups that contained particular experiential structures and logical structure elements are shown.

\subsection{Nominal Group with One Modification}

The nominal group with one modification means that the nominal group which only consists of one experiential structure element that precedes and/or follows the Thing.

\subsubsection{Pre Modification}

This part of the analysis presents one experiential structure element which precedes the Thing. The Thing elements found in the data are common noun.

(N.11) ....security in the world.

\begin{tabular}{cc}
\hline The & world \\
\hline $\mathrm{D}$ & $\mathrm{T}$ \\
$\mathrm{M}$ & $\mathrm{H}$
\end{tabular}

Data (N.11) shows that the nominal group "the world" consists of two experiential structure elements. These two elements are Deictic and Thing. Deictic element in this nominal group is identified by a definite article "the". According to the theory used, the definite article "the" functions as specific Deictic, because the definite article "the" is a demonstrative determiner. And the Thing element in this nominal group is 
indicated by a common noun "world". The word "world" is categorized as a common noun because it is a noun that is common to a class of referent. The common noun "world" is the semantic core of this nominal group.

Therefore, the nominal group "the world" has D+T structure. Data (N.11) shows that Deictic element functions as Modifier because Deictic element modifies Thing. Therefore, the noun "world" is the Head of the nominal group because Thing element functions as Head and it is modified by an article "the".

\subsubsection{Mix Modification}

This part of the analysis presents one experiential structure element which precedes and follows the Thing. The Thing element found in the data is a common noun.

(N.34) I know from many conversations with the Secretary General - we've been at....

\begin{tabular}{ccc}
\hline Many & conversations & $\begin{array}{c}\text { [with the } \\
\text { Secgen] }\end{array}$ \\
\hline $\mathrm{N}$ & $\mathrm{T}$ & $\mathrm{Q}$ \\
$\mathrm{M}$ & $\mathrm{H}$ & $\mathrm{M}$ \\
\hline
\end{tabular}

Data (N.34) shows that the nominal group "many conversations with the Secretary General" consists of three experiential structure elements. These elements are Numerative, Thing, and Qualifier. Numerative element in this nominal group is indicated by the indefinite quantitative "many". The numerative element "many" is categorized as an inexact number in Numerative element of nominal group. Another element produced is Thing which is indicated by the common noun "conversations". The last element is Qualifier which is indicated by the prepositional phrase "with the Secretary General".

The nominal group has $\mathrm{N}+\mathrm{T}+\mathrm{Q}$ structure. This nominal group has mix modification because it consists of premodifier and postmodifier. Thing element has function as Head of the nominal group and Numerative and Qualifier elements have function as Modifier.

\subsection{Nominal Group with Two Modifications}

The nominal group with two modifications means that the nominal group which consists of two experiential structure elements that precede the Thing element. However, there is only Qualifier element that follows the Thing.

\subsubsection{Pre Modification}

This part of the analysis presents two experiential structure elements which precede the Thing. The Thing elements found in the data are common noun.

(N.15) ....in all of my first meetings, I intend to....

\begin{tabular}{ccc}
\hline My & first & meetings \\
\hline $\mathrm{D}$ & $\mathrm{N}$ & $\mathrm{T}$ \\
& $\mathrm{M}$ & $\mathrm{H}$
\end{tabular}

Data (N.15) shows that the nominal group "my first meetings" consists of three experiential structure elements. These elements are Deictic, Numerative, and Thing. The Deictic element in this nominal group is indicated by the specific possessive determiner "my". Another element produced is Numerative which is indicated by the ordering numerative "first" and the last element is Thing which is indicated by the common noun "meetings". The Thing element "meetings" is a semantic core of this nominal group and the Thing element "meetings" is specified by the possessive Deictic features of possession "my". Therefore, it is categorized as specific deictic.

In the nominal group "my first meetings", there are two logical structure elements found, namely: Head and Modifier elements. According to Halliday (2014:390) the nominal group 
can be distinguished from the two positions by using the terms Premodifier and Postmodifier. The Head of this nominal group is indicated by the Thing element, which is modified by Deictic and Numerative elements. Therefore, Deictic and Numerative elements of the nominal group have function as Premodifier because it appears before Head element.

\subsubsection{Mix Modification}

This part of the analysis presents two experiential structure elements which precede the Thing element, but only one experiential structure element found which follows the Thing. The Thing element found in the data is common noun.

(Nnon.82) ....towards our shared goals of peace, development, and human rights.

\begin{tabular}{cccc}
\hline our & shared & goals & $\begin{array}{c}\text { [of peace, ... } \\
\text { human rights] }\end{array}$ \\
\hline $\mathrm{D}$ & $\mathrm{C}$ & $\mathrm{T}$ & $\mathrm{Q}$ \\
& $\mathrm{M}$ & $\mathrm{H}$ & $\mathrm{M}$ \\
\hline
\end{tabular}

Data (Nnon.82) shows that the nominal group "our shared goals of peace, development, and human rights" consists of four experiential structure elements. These elements are Deictic, Classifier, Thing, and Qualifier. Deictic in this nominal group is indicated by possessive Deictic features "our". Another element produced is Classifier which is indicated by the verb "shared". The element Thing is indicated by the common noun "goals". The verb "shared" is considered Classifier element because it indicates a particular subclass of the Thing question. Furthermore, "shared" as a word of the verb class the sense of a simple present form (passive); "shared goals" means 'goals which are shared'.

The nominal group "our shared goals of peace, development, and human rights" has $\mathrm{D}+\mathrm{C}+\mathrm{T}+\mathrm{Q}$ structure. Deictic, Classifier, and Qualifier elements have function as Modifier because it modifies the Head "goals". Deictic and Classifier elements are called premodifiers because they appear before Head, meanwhile, Qualifier element is called postmodifier.

\subsection{Nominal Group with Three Modifications}

The nominal group with three modifications means that the nominal group which consists of three experiential structure elements that precede the Thing element. However, there is only one experiential element found that follows the Thing element.

\subsubsection{Pre Modification}

This part of the analysis presents three experiential structure elements which precede the Thing. The Thing elements found in the data are common noun.

(N.31) ....President Obama raised in his second Inaugural Address and then again in....

\begin{tabular}{|c|c|c|c|}
\hline his & second & Inaugural & Address \\
\hline $\mathrm{D}$ & $\mathrm{N}$ & $\mathrm{C}$ & $\mathrm{T}$ \\
\hline \multicolumn{3}{|c|}{ M } & $\mathrm{H}$ \\
\hline
\end{tabular}

Data (N.31) shows that the nominal group "his second Inaugural Address" consists of four experiential structure elements. These four elements are Deictic which is identified by the possessive determiner "his". According to Halliday (2014), the possessive determiner "his" functions as specific Deictic. Another nominal group produced is Numerative which is indicated by "second".

The following nominal group is Classifier which is indicated by "Inaugural". It is considered Classifier element because it indicates a particular subclass of the Thing question; it is an Inaugural Address, not a final or latest Address. Furthermore, the Thing in this nominal group is indicated by a the common noun "Address. 
Therefore, from all of those elements identified, the nominal group "his second Inaugural Address" has $\mathrm{D}+\mathrm{N}+\mathrm{C}+\mathrm{T}$ structure. Meanwhile, for the logical structure element, this nominal group consists of two elements; Head and Modifier. The Head of this nominal group is indicated by Thing. $\mathrm{D}+\mathrm{N}+\mathrm{C}$ has function as Modifier (Premodifier) because it appears before Head.

\subsection{Nominal Group without Modification}

The nominal group without modification means the nominal group in which there is no experiential structure element that precedes or follows the Thing element.

(N.10) First of all, with respect to North Korea, this....

\begin{tabular}{c}
\hline North Korea \\
$\mathrm{T}$ \\
$\mathrm{H}$
\end{tabular}

Data (N.10) shows that the nominal group "North Korea" consists of one experiential structure element. This element is Thing. Thing in this nominal group is indicated by a proper name "North Korea"; a name for a particular place and it is also the semantic core of this nominal group. Meanwhile, there is only one logical structure element found, namely; Head element. Thing element in this nominal group has function as Head of the nominal group. This nominal group has only $\mathrm{T}$ structure.

\section{Conclusion}

In analyzing 440 nominal groups found in John Kerry and Ban Ki-moon's speech in United States based on the Theory of Nominal Group proposed by Halliday and Matthiessen, it can be concluded that in the experiential structure, all kinds of experiential elements occur in both John Kerry and Ban Ki-moon's speech. They are Deictic (specific and non-specific), Numerative (exact and inexact), Epithet (experiential and interpersonal), Classifier, Qualifier (embedded phrase and embedded clause), and Thing (personal pronoun, proper name, and common noun). In analyzing the experiential structures of those nominal groups, it can be concluded that there are twenty-seven experiential structures of nominal group produced by John Kerry and Ban Ki-moon. T structure becomes the most frequent structure that occurs followed by $\mathrm{D}+\mathrm{T}$ and $\mathrm{D}+\mathrm{T}+\mathrm{Q}$ structure.

Furthermore, in the logical structure, all of the logical elements also occur in John Kerry and Ban Ki-moon's speech. They are Head and Modifier (Premodifier and Postmodifier). From the structures found, John Kerry and Ban Ki-moon's nominal group structures have a simple construction and it emphasizes Thing without adding some information.

\section{References}

Bangun, Kartini Br. 2014. "Experiential and Logical Structures within Karo Batak Nominal Groups: A Study in Systemic Functional Linguistics", the IOSR journal of Humanities and Social Science (IOSR-JHSS) Volume 19, Issue 9, Ver. III (Sep. 2014). http://iosrjournals.org/iosrjhss/papers/Vol19-issue9/Version3/H019934352.pdf (accessed on February 17th, 2017)

Bloomfield, L. (1933). Language. New York: Holt Rinehart Winston.

Bloor, Thomas, Bloor, Meriel. 2004. The Functional Analysis of English. 2nd ed. London: Edward Arnold, 2004.

Davies, A. (1991). The native speaker in applied linguistics. Edinburgh: Edinburgh University Press. 
Halliday, Michael A K.1994. Functional Grammar. 2nd ed. London: Edward Arnold

Halliday, Michael A K.1961. Categories of the theory of grammar: The Collected Works of M. A. K. Halliday Volume One: On Grammar.

Halliday, M. A. K. \& Matthiessen, C. M. I. M. (2014). An Introduction to Functional Grammar (Fourth Edition). London: Routledge.

Hornby, A.S. 2000. Guide to patterns and usage in English 2nd Edition. London: Oxford University Press.

Karina, Lintang. 2013. "Structures of Nominal Group of An Opinion Articles in the Jakarta Post" (undergraduate thesis). Semarang: Dian Nuswantoro University.

Sapire, Edward. 1921. Language: an Introduction to the Study of Speech. New York: Harcourt, Brace 